\title{
REVITALISASI RUANG TERBUKA HIJAU DI WILAYAH URBAN: ELABORASI HASIL FOCUS GROUP DISCUSSION (FGD) PERENCANAANTAMAN MAJU BERSAMA DI KELURAHAN GANDARIA UTARA DI JAKARTA SELATAN
}

\author{
Moh. Sanjiva Refi Hasibuan ${ }^{1 *}$, Lasmaria Sidabutar ${ }^{2}$ \\ ${ }^{\text {I} P r o g r a m ~ S t u d i A r s i t e k t u r ~ L a n s k a p, ~ F a k u l t a s ~ T e k n i k S i p i l d a n ~ P e r e n c a n a a n, ~ I n s t i t u t ~ S a i n s ~ d a n ~ T e k n o l o g i ~ N a s i o n a l, ~}$ \\ Jakarta, Indonesia \\ ${ }^{2}$ Member of Indonesian Landscape Architect Association, Jakarta, Indonesia \\ *Penulis Korespondensi : refi.hasibuan@gmail.com
}

\begin{abstract}
Abstrak
Taman Maju Bersama (TMB) adalah salah satu program pemerintah Provinsi DKI Jakarta dalam menyediakan ruang terbuka hijau dikawasan perkotaan. Dalam proses perencanaann ya, program TMB melibatkan partisipasi aktif masyarakat dengan mengadakan kegiatan Focus Group Discussion (FGD) untuk mendapatkan masukan-masukan (input) yang positif demi kelancaran program TMB. Kegiatan FGD ini melibatkan instansi pemerintah tingkat kelu rahan dan kecamatan, RT, RW, tokoh masyarakat, perwakilan warga lokal, kelompok PKK, Ka rang Ta runa, hingga komunitas y ang terdapat pada daerah tersebut. FGD dilaksanakan dalam tiga tahap yaitu pada tahap awal perencanaan, tahap penyampaian konsep dan desain, serta tahap akhir sosialisa si desain akhir kepada masyarakat. Teknik pelaksanaan FGD yang digunakan adalah diskusi a tau tanya jawab secara langsung dan tertulis. Teknik tertulis lebih efektif digunakan dalam mendapatkan ide, masukan, dan komentar dari masyarakat. Hasil dari kegiatan FGD akan menjadi dasar pertimbangan dan masukan bagi konsultan perencana dalam merencanakan dan merancang sebuah taman yang fungsional dan estetis.
\end{abstract}

Kata Kunci: Ta man Maju Bersama; Focus Group Discussion; Partisipasi; Perencanaan; Taman.

\begin{abstract}
Taman Maju Bersama (TMB) is one of the DKI Jakarta Provincial Government programs in providing green open space in urban areas. In the planning process, the TMB program involves the active participation of the community by holding Focus Group Discussion (FGD) activities to obtain positive inputs for the smooth running of the TMB program. This FGD activity involved government agencies at the village and sub-district level, $R T, R W$, communityleaders, representatives of local residents, $P K K$ groups, Youth Organizations, and communities in the area. The FGD was carried out in three stages, namely in the initial stages of planning, the stage of conceptualdeliveryand design, and the final stage of the final design socialization to the community. The FGD implementation technique used was direct and written discussion or question and answer. Written techniques arefelt to be more effective in getting ideas, input, and comments from the public. The results of the FGD activities will be the basis for consideration and input for planning consultants in planning and designing a park that is functional and aesthetic.
\end{abstract}

Key words: Taman Maju Bersama; Focus Group Discussion; Participation; Planning; Park.

\section{PENDAhuluan}

Taman Maju Bersama (TMB) merupakan program pemerintah DKI Jakarta yang masuk dalam Rencana Pembangunan Jangka Menengah Daerah (RPJMD) 2018-2022 da lam menyediakan Ruang Terbuka Hijau (RTH). Pemerintah DKI Jakarta giat melakukan perencanaan dan pembangunan TMB secara bertahap hingga tahun 2022. Konsep taman ini sedikit berbeda dengan taman lain di Jakarta seperti pada program sebelumnya yaitu Ruang Publik Terpadu Ramah Anak (RPTRA). Perbedaan tersebut antara la in terletak pada konsep pendekatan dalam proses perencanaan dan penataan ruangnya. Pada tahap perencanaan, TMB mengutamakan pendekatan partisipasi masyarakat yakni masyarakat yang tinggal disekitar taman dilibatkan secara langsung dalam proses perencanaan, penga wasan, pemanfaatan, dan pengelolaan. Sementara dalam konsep penataan ruangnya, TMB harus mampu menambah persentase RTH Kota dengan menyediakan a rea hijau yang lebih dominan daripada a rea terbangun. Ketersediaan a rea hijau yang lebih besar ini diharapkan dapat berfungsi sebagai area resapan air dan 
memberikan kenyamanan dan kesehatan bagi masyarakat dan lingkungan melalui fungsi ekologisnya.

Namun secara tipologi menurut Peraturan Menter Pekerjaan Umum No.5 Tahun 2008 tentang Pedoman Penyediaan dan Pemanfaatan Ruang Terbuka Hijau di Kawa san Perkotaan, RPTRA dan TMB setara dengan taman RT, taman RW, dan taman Kelurahan yang termasuk kategori ruang terbuka hijau publik kecil dengan luasan sekitar $500-9.000 \mathrm{~m} 2$.

Banyak pendekatan yang dapat dilakukan untuk melibatkan masyarakat dalam perencanaan pembangunan. Focus Group Discussion (FGD), salah satunya. Menurut Indrizal(2014), FGD semakinbanyak digunakan sebagai metode, teknik dan instrumen penelitian, termasuk untuk kegiatan pengkajian, penjajagan, perencanaan, pelaksanaan, pemantauan dan evaluasi pembangunan seperti yang dilaporkan oleh Alfa qiet al. (2020), Wiwa ha et al. (2016), Syahadat et al. (2014), dan Mahyudin et al. (2011). FGD menjadi pilihan karena prinsipnya dalammenentukan keputusan merupakan hasil dari brain storming oleh stakeholders baik internal maupun eksternal sehingga keputusan yang diambil bersifat komprehensif.

Ada pun tujuan dari pengabdian dengan menggunakan pendekatan FGD ini a dalah untuk menampung masukan berupa aspirasi, ide dan konsep. Dengan demikian, aspirasi masyarakat dapat ditampung sebagai bahan pertimbangan untuk mewujudkan sebuah taman publik yang fungsional dan estetis. Keterlibatan masyarakat da la $m$ proses perencanaan ini diharapkan dapat menjadi masukan (input) penting bagi konsultan perencana dalam menyusun konsep dan penataan taman yang sesuai dengan kebutuhan masyarakat.

\section{METODOLOGI}

Pera latan dan bahan yang digunakan dalam proses FGD antara la in yaitu, media la ptop dan LCD, pointer, sticky notes, spidol warna, kertas karton ukuran A2, whiteboard marker, dan kamera digital. Laptop, LCD, dan pointer digunakan sebagai alat untuk presentasi materi oleh konsultan perencana. Sticky notes, spidol warna, karton A2, dan whiteboard marker digunakan sebagai media untuk mencatat masukan, ide, dan aspirasi dari masyarakat. Sementara kamera digital diguna kan untuk dokumentasi sela ma kegiatan.

Peserta FGD terdiri a tas tim konsultan perencana yang berjumlah 4 (empat) orang dengan latar belakang keahlian di bidang Arsitektur Lanskap, Arsitektur, dan Sosiolog. Kemudian didampingi oleh tim teknis dari bidang Jalur Hijau Dinas Pertamanan dan Hutan Kota, Provinsi DKI Jakarta. Serta dihadiri oleh perwakilan dari pihak Kecamatan Pasar Minggu, Kelurahan Jati Pa dang, Ketua RT dan RW di lingkungan Jl. Haji Raya, perwakilan ibu-ibu PKK, perwakilan Karang Tanuna, serta beberapa perwakilan dari masyarakat dan komunitas.
Kegiatan Focus Group Discussion (FGD) ini dilakukan di Kantor Kelurahan Gandaria Utara, Kecamatan Kebayoran Baru, Jakarta Selatan. FGD dilakukan sebanyak 3 (tiga) kali, mulai dari tahap awal perencanaan (FGD-1), pemaparan konsep dan hasil pradesa in (FGD-2), dan sosialisasi/pemaparan hasil desain akhir (FGD-3). Ada pun pembahasan dibatasi hanya pada proses FGD-1 yang dilakukan pada bulan Mei 2019 dan FGD-2 yang dila kukan pada bulan September 2019. Adanya rentang waktu yang cukup lama antara kegiatan FGD 1 dan FGD 2 ini karena proses analisis dan penyusunan konsep yang dilakukan oleh konsultan perencana serta a sistensi dengan dinas terkait dalam hal ini bidang jalur hijau Dinas Pertamanan dan Hutan Kota, DKI Jakarta. Secara umum, proses tahapan perencanaan TMB Jl. Haji Raya di Kelurahan Ga ndaria Utara yang meliputi kegiatan FGD dida lamnya da pat dilihat pada Gambar 1.

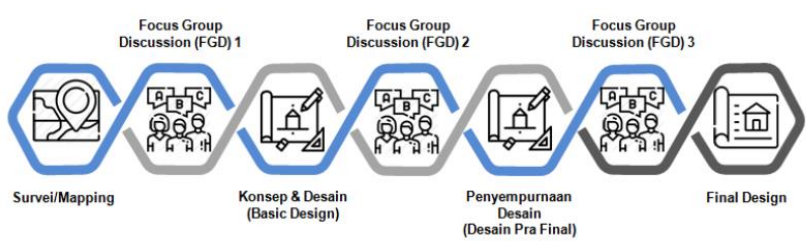

Gambar 1. Kegiatan FGD da lam tahapan proses perencanaan Taman Maju Bersama

\section{HASIL DAN PEMBAHASAN}

\section{Focus Group Discussion 1 (FGD-1)}

Kegiatan FGD-1 dilakukan pada bulan Mei 2019 bertempat di kantor Kelurahan Gandaria Utara, Jakarta Selatan. Kegiatan dibuka dan diawali den gan sambutan dari Lurah Gandaria Utara dan perwakilan dari Dinas Perta manan dan Hutan Kota DKI Jakarta. Selanjutnya kegiatan FGD dilanjutkan dengan presentasi dari tim konsultan untuk menjelaskan data-data hasil kegiatan survei la pangan pada lokasi yang direncanakan akan dibangun Taman Maju Bersama. Kegiatan survei ini sebelumnya sudah dilakukan oleh tim konsultan untuk melihat, mengamati, dan mendokumentasikan kondisi eksisting lokasi taman. Kemudian setelah dilakukan pemaparan hasil survei, FGD selanjutnya dipandu oleh seorang Sosiolog dari tim konsultan perencana. FGD memerlukan fasilitator-moderator (pemandu diskusi) yang memiliki keterampilan tinggi ka rena halini sangat berpengaruh terhadap hasil (Indrizal, 2014).

Teknis pelaksanaan FGD dilakukan dengan cara membagikan secarik kertas tempel (sticky notes) dan alat tulis kepada masyarakat yang hadir kemudian mereka diminta untuk menuliskan permasalahan apa saja yang terjadi dan dira sakan di lingkungan mereka saat ini. Setelah selesai, kertas tersebut dikumpulkan kepada tim konsultan untuk kemudian dicatat sebagai rangkuman permasalahan pada kertas karton yang ditempel di depan ruangan FGD. Sela njutnya, peserta FDG diminta kembali menuliskan bentuk kegiatan apa saja yang diinginkan nantinya yang a kan diadakan pada ta man maju bersama ini. Kegia tan y ang dituliskan dapat lebih dari satu sesuai kebutuhan dan memperhatikan 
ketersediaan lahan. Bentuk-bentuk kegiatan yang diinginkan oleh peserta sebagai perwakilan dari masyarakat lalu dituliskan pada karton rangkuman. Langkah selanjutnya adalah menuliskan fasilitasfasilitas taman apa saja yang dibutuhkan oleh masyarakat di dalam taman maju bersama nanti. Kebutuhan fasilitas yang dibutuhkan juga dapat ditulis lebih dari satu. Diharapkan fasilitas yang menjadi masukan masyarakat ini adalah fasilitas yang benarbenar dibutuhkan dan prioritas bukan sekedarkeinginan individu semata. Fasilitas yang diusulkan hans mengakomodasi kebutuhan pengguna dari berbagai tingka tan u sia terutama anak-anak. Mayoritas pengguna ta man adalah anak-anak baik perempuan maupun lakilaki dengan persentase terbesar sementara sisanya adalah dewasa dan lansia (Prakoso \& Dewi, 2018).

Ahli sosiolog kemudian memandu jalannya kegiatan FGD untuk mendiskusikan masalah pengelolaan taman ini nantinya setelah selesai dibangun. Peserta diminta proaktif memberikan pendapat dan saran terkait pengelolaan taman. Pengelolaan sendiri terbagi menjadi 2 (dua), yaitu pengelolaan fisik, yang menupakan pemeliharaan terhadap kondisifisik ta man baik elemen hardscape maupun softscape; dan pengelolaan kegiatan, yang merupakan tanggungjawab masyarakat setempat untuk menyusun program kegiatan, jadwal, penanggungjawab, dan sebagainya. Pengelolaan fisik taman seperti pemeliharaan dan keamanan disepakati akan menjadi tanggungjawab penuh Dinas Pertamanan dan Hutan Kota Provinsi DKI Jakarta. Adapun sumberdaya manusia yang bekerja memelihara dan menjaga keamanan taman nantinya akan melibatkan masyarakat setempat dengan skema perekrutan petugas yang sudah disusun oleh pihak dinas. Sedangkan untuk pengelolaan kegiatan sepenuhnya diserahkan kepada masyarakat setempat yang diharapkan melibatkan semua kalangan seperti Ibu PKK, Karang Tanuna, Komunitas seni budaya, dan sebagainya. Diharapkan dengan adanya pengelolaan ini dapat mewujudkan tujuan pembangunan Taman maju Bersama (TMB) yaitu tidak hanya sebagai ruang terbuka hijau tetapijuga dapat dimanfaatkan oleh masyarakat sebagai ruang interaksi, olahraga, serta berbagai kegiatan positif la innya. Hasil kegia tan FGD-1 dapat dilihat pada tabel 1.

Tabel 1. Ha sil rangkuman kegiatan FGD-1

\begin{tabular}{|c|c|}
\hline NO & PERMASALAHAN \\
\hline 1 & $\begin{array}{l}\text { Masyarakat menginginkan lingkungan mereka } \\
\text { indah }\end{array}$ \\
\hline 2 & Tidak a da area/lapangan untuk acara warga \\
\hline 3 & $\begin{array}{l}\text { Tidak ada ruang untuk berinteraksi sesama } \\
\text { warga }\end{array}$ \\
\hline 4 & $\begin{array}{l}\text { Tidak a danya la pangan futsal ba gi anak-anak } \\
\text { dan pemuda }\end{array}$ \\
\hline 5 & $\begin{array}{l}\text { Pemuda banyak yang nongkrong dan trek-trekan } \\
\text { motor dijalanan }\end{array}$ \\
\hline 6 & Masalah sampah \\
\hline 7 & $\begin{array}{l}\text { Area sekitar taman pernah banjir saat musim } \\
\text { hujan }\end{array}$ \\
\hline
\end{tabular}

\begin{tabular}{|r|l|}
8 & $\begin{array}{l}\text { Pada lahan renca na ta man belum ada pagar } \\
\text { sehingga banyak yang buang sampah ke lokasi }\end{array}$ \\
\hline NO & KEGIATAN \\
\hline 1 & Senam, senam lansia \\
3 & Menjadi tem pat kegiatan pelatihan \\
4 & Futsaldan Jogging \\
5 & Mempat lomba dan bermain bagia nak-anak \\
6 & Kegia tan menanam/apotik hidup \\
7 & Kolam ikan untukedukasi bagi anak-anak \\
\hline NO & FASILITAS \\
\hline 1 & Area parkir sepeda motor \\
2 & Lapanganfutsal \\
3 & Jogging track \\
4 & Jalur refleksi \\
5 & Area bermain bagiba lita \\
6 & Ruang terbuka \\
7 & Toilet umum \\
8 & Panggung tempat pementasan \\
9 & Tempatduduk dan shelter \\
10 & Area bercocoktanam \\
11 & Ramp untuk disabilitas \\
\hline NO & PENGELOLAAN \\
\hline 1 & Pengelolaan fisik: pera watan taman dan \\
& keamanan menjadi tanggungjawab Dinas \\
2 & Pertamanan dan Hutan Kota, Prov. DKI Jakarta \\
& Pengelolaan Kegiatan: menjadi tanggungjawab \\
& Targa masyarakat antara lain Ibu PKK, Karang \\
& \\
\hline
\end{tabular}

Metode yang digunakan dalam menampung aspirasi masyarakat dengan teknis menuliskan ide, masukan, dan pendapat pada secarik kertas (sticky notes) lebih efektif dibandingkan meminta pendapat dan masukan masyarakat secara lisan atau langsung. Hal ini disebabkan oleh faktor ketidakmampuan setiap peserta dalam menyampaikan pendapatnya secara lisan. Konsentrasi, pengalaman, penguasaan materi dan pengetahuan terhadap gagasan yang akan disampaikan merupakan faktor-faktor yang mempenganuhi ketidakpercayaan diri seseorang dalam menyampaikan pendapat (Pradana, 2016). Komunikasi yang efektif dalam sebuah kelompok terjadi jika setiap anggota kelompok saling berinteraksi dan memiliki andil yang besar dalam memberikan masukan-masukan dalam memecahkan masalah bersama (Tutiasri, 2016). Penyampaian pendapat secara tertulis lebih tepat dan cepat digunakan da lam kegia tan FGD yang kemudian hasil kumpulan pendapat tersebut dirangkum dan dibahas secara bersama-sama dengan dipandu oleh seorang pemimpin diskusi dalam hal ini dipimpin oleh seorang sosiolog yang sudah ahli dan terbiasa berinteraksi dengan masyarakat dari berbagai karakter dan budaya.

\section{Focus Group Discussion 2 (FGD-2)}

Hasil yang diperoleh dari kegiatan FGD-1 benupa permasalahan, kegia tan, dan fasilita s menjadi masukan dan pertimbangan bagi tim konsultan perencana dalam menyusun konsep serta membuat desain yang sesuai 
untuk TMB Jl. Haji Raya. Kekuatan utama metode FGD terbukti dapat memberikan data yang lebih mendalam. lebih informatif, dan lebih bernilai dibanding metode la innya (Afiyanti, 2008). Setelah proses desain selesai serta telah melewati beberapa kali a sistensi dengan tim teknis daridinas maka selanjutnya dijadwalkan kegiatan FGD yangke-2.

FGD-2 dilakukan pada bulan September 2019 bertempat di kantor Kelurahan Gandaria Utara, Jl. Taman Radio Dalam VII, Kebayoran Baru, Jakarta Selatan. Fokus kegiatan pada FGD-2 ini adalah pemaparan hasil konsep dan desain TMB Jl. Haji Raya oleh tim konsultan perencana serta diskusi tanya jawab antara tim konsultan dengan peserta FGD. Adapun pera latan dan bahan yang disia pkan untuk kegia tan ini antara lain laptop dan LCD sebagai media presentasi, serta ga mbar-gambar ilustra si desain dalam bentuk 3 dimensi (3D) yang sudah dicetak dalam ukuran A3 berwarna. Gambar-gambar ini akan menjadi media untuk catatan dan masukan dari peserta FGD. Media gambar termasuk sa luran komunikasi yang digunakan untuk memindahkan pesan dari pemberi pesan kepada penerima (Kurniati, 2016).

Kegiatan FGD-2 dihadiri oleh peserta yang terdiri atas perwakilan dari Kecamatan Kebayoran Baru, Kelurahan Gandaria Utara, Ketua RT dan RW setempat, serta beberapa perwakilan masyarakat yang diundang. Kegiatan dimulai dengan presentasi oleh tim konsultan perencana dengan memaparkan secara jelas dan detail mengenai konsep dan desain Taman Maju Bersama Jl. Haji Raya(Gambar 2).

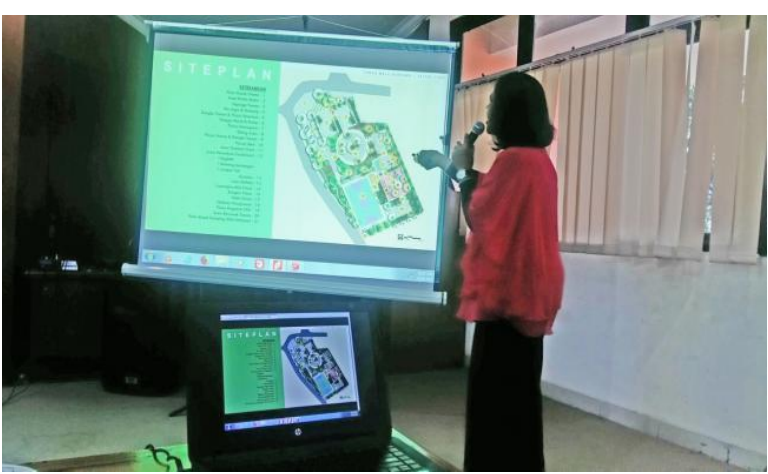

Gambar 2. Pemaparan konsep dan desain TMB oleh konsultan perencana.

Setelah penyampaian materi oleh tim konsultan perencana kemudian dilanjutkan oleh sesi diskusi berupa tanya jawab antara peserta dan tim konsultan yang dipandu oleh sosiolog (Gambar 3). Peserta diminta menyampaikan pertanyaan, masukan, serta komentar terkait konsep dan desain yang sudah dibuat oleh konsultan perencana. Secara umum, peserta setuju dengan konsep dan penataan taman yang sudah dibuat namun mereka lebih menyoroti permasalahan banjir atau genangan air y ang selalu terjadi di loka si tenutama pada saat musim penghujan. Peserta mengkhawatirkan permasalahan ini masih akan tetap terjadi di lokasi ketika taman maju bersama ini nantinya selesai dibangun. Namun, tim konsultan sudah mengantisipasi permasalahan ini dengan membuat desain dan menata saluran drainase sedemikian rupa sehingga masalah banjir a tau genangan air ketika hujan bisa teratasi.

Sesi diskusi selanjutnya membahas mengenai usulan nama taman yang akan digunakan sebagai identitas TMB Jl. Haji Raya. Peserta diminta menyampaikan beberapa usulan nama taman yang nantin ya a kan dipilih satu nama secara mufakat sebagai nama taman. Sosiolog memandu jalannya diskusi dengan memberikan arahan dan gambaran terkait pemberian nama yaitu namataman dapat menyesuaikan na ma loka si tempat dibangunnya taman, atau nama yang secara historis melekat pada tempat tersebut. Nama taman juga harus unik dan mudah diingat. Dari beberapa usulan nama yang disampaikan oleh peserta akhirnya disepakati sebuah nama yaitu Taman Gantara yang merupakan singkatan dari Taman Gandaria Utara. Nama ini akan digunakan oleh tim konsultan dalamdesain sebagai identitas taman dalam bentuk signage yang ditempatkan pada area gerbang masuktaman.

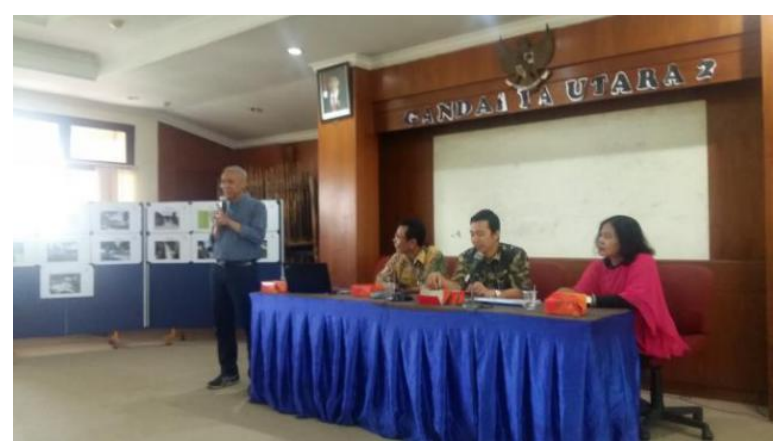

Gambar 3. Sesi diskusi tanya jawab a ntara peserta FGD dengan tim konsultan perencana.

Sesi terakhir dalam kegiatan FGD-2 ini adalah sesi komentar tertulis terhadap desain TMB. Peserta FGD diminta menuliskan komentar a tau ma sukan terhadap desa in taman yang sudah dibuat pada gambar-gambar ilustra si 3D taman yang sudah dicetak berwama pada kertas ukuran A3 (Gambar 4.). Ma sing-masing peserta dapat menuliskan komentar apapun yang ingin disampaikan terkait desain baik yang sudah didiskusikan. Cara ini a mpuh untuk memperkuat hasil kesimpulan dari kegiatan FGD. Menurut Boateng (2012), dalam sebuah penelitian sosial kegiatan FGD perlu dilengkapi dengan metode la in untuk mendukung data u tama. Hasil FGD ha rus bisa memastikan distribusi peluang yang adil kepada semua peserta untuk memberikan suaranya agar keputusan yang diperoleh bukan hasil dari suara kelompok atau seseorang yang dominan dalam kelompok. Peserta terlihat lebih antusias pada sesi ini karena mereka bisa melihat langsung dan memahami wujud desain taman dalam gambar berwarna 3 dimensi serta dapat menuliskan langsung komentar pada gambar. Gambar melengkapi bahasa lisan dan tulisan dalam kaitan menjelaskan keberadaan suatu obyek serta mampu memaparkan 
lebih rinci dan membatasi rentang interpretasi (Istanto, 2000).
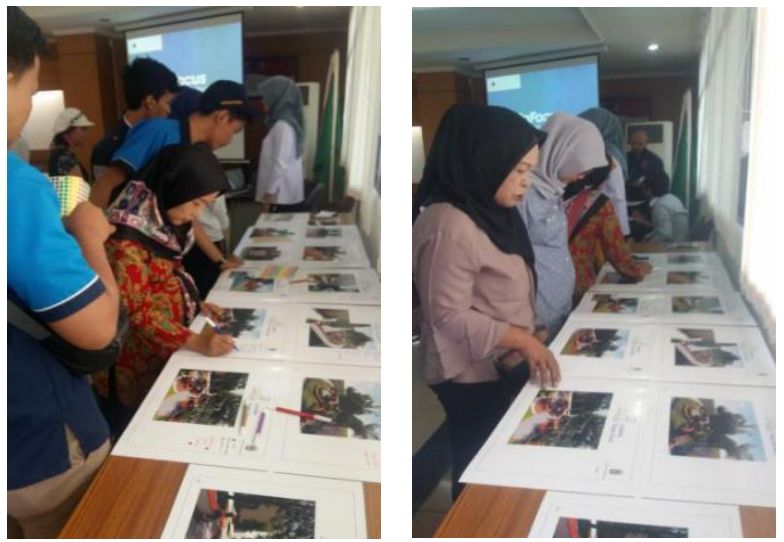

Gambar 4. Peserta FGD menuliskan komentar dan ma sukan terkait desain pada ga mbar ilustrasi taman.

Berba gai komentar dan masukan yang dituliskan oleh peserta di atas kertas gambar akan menjadi bahan evaluasi dan pertimbangan bagi tim konsultan perencana dalam memperbaiki ataupun melengkapi desain yang telah dibuat. Tim konsultan akan mempertimbangkan berbagai aspek kesesuaian dari ha sil analisis, konsep dan kebutuhan masyarakat dengan komentar dan masukan yang diberikan oleh peserta FGD.

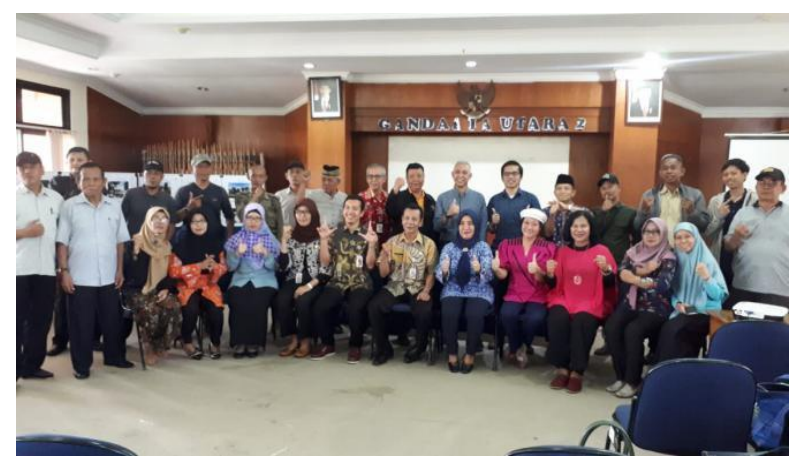

Gambar 5. Sesi foto bersama kegiatanFGD dikantor Kelura han Gandaria Utara.

\section{KESIMPULAN}

Kegiatan FGD menjadi tahapan penting dalam sebuah proses perencanaan taman karena melibatkan masyarakat lokal yang akan menjadi pengguna dan pengelola taman serta dapat memberikan input yang positif bagi tim konsultan perencana. Proses penyampaian pendapat dalam kegiatan FGD ini lebih efektif dilakukan secara tertulis karena tidak semua peserta memiliki keberanian dalam menyampaikan pendapatnya secara lisan. Penyampaian pendapat secara tertulis lebih mampu menjaring banyak ide dan masukan dari peserta dibandingkan diskusi tanya jawab langsung secara lisan. Secara umum masyarakat merasa puas dalam setiap pelaksanaan FGD dan memberikan banyak informasi untuk keberlanjutan TMB kedepannya sebagai RTH yang bernilai fungsional dan estetis. Tindak lanjut dari kegiatan pengabdian ini adalah seluruh partisipasi mereka telah ditampung dan siap untuk diolah dan dianalisis lebih lanjut oleh konsultan perencana TMB. Dengan demikian baik masyarakat maupun perencana, keduanya terbantu denga $n$ a danya kegiatan pengabdian ini.

\section{UCAPAN TERIMA KASIH}

Penulis men gucapkan terima kasih kepada bidang Jalur Hijau Dinas Pertamanan dan Hutan Kota Provinsi DKI Jakarta yang telah memfasilitasiterla ksananya kegiatan FGD dan pengarahan selama berlangsungnya proses perencanaan. Ucapan terima kasih juga disampaikan kepada segenap instansi Kelurahan Gandaria Utara, Kota Jakarta Selatan beserta seluruh perwakilan masyarakat yang menjadi bagian dari kegiatan FGD-1 maupun FGD-2 atas kerjasama yang baik dan dukungannya.

\section{DAFTAR PUSTAKA}

Afiyanti, Y. (2008). Focus Group Discussion (Diskusi Kelompok Terfokus) sebagai Metode Pengumpulan Data Penelitian Kualitatif. Jurnal Keperawatan Indonesia, 12(1), 58-62.

Alfaqi, M.F., Shofa, A.M.A., Mawarti, R.A., dan Habibi, M.M. (2020). Meningkatkan Pemahaman Generasi Muda terhadap Peran E.F.E. Douwes Dekker pada Era Pergerakan Nasional Melalui Focus Group Discussion (FGD) Guru Bangsa. Jurnal Praktisi dan Dedikasi, 3(1), 21-27.

Boateng, W. (2012). Evaluating the Efficacy of Focus Group Discussion (FGD) in Qualitative Social Research. International Journal of Business and Social Science, 3(7), 54-57.

Istanto, F.H. (2000). Gambar sebagai Alat Komunikasi Visual. Nirmana: Jurnal Desain Komunikasi Visual, 2(1), 23-35.

Indrizal, E. (2014). Disku si Kelompok Terarah. Jantro: Jurnal Antropologi, 16(1), 75-82.

Kurnia ti, D.P.Y.(2016). Modul Komunikasi Verbal dan Non Verbal. Universitas Udayana: Fakultas Kedokteran.

Mahyudin, R.P., Mashuri, A., Shadiq, F., dan Azis, Y. (2011). Kajian Perencanaan Pembentukan TPA Regional Rencana Daerah Layanan Kota Banjarbaru, Banjarmasin dan Martapura. EnviroScienteae, 7(2011), 113-123.

Peraturan Menteri PU No.5. (2008). Pedoman Penyediaan dan Pemanfaatan Ruang Terbuka Hijau di Kawasan Perkotaan. Republik Indonesia.

Pradana, I.D. (2016). Kepercayaan Diri dalam Penyampaian Pendapat pada Mahasiswa Awal Universitas Muhammadiyah Surakarta. Skripsi. Universitas Muhammadiyah Surakarta.

Prakoso, S. dan Dewi, J. (2018). Panduan Rancang Taman Lingkungan Berdampak Rasa Kelekatan pada Anak (p. 30). Tangerang: Fakultas Desain UPH.

Syahadat, R.M., Arifin, N.H.S., dan Arifin, H.S. (2014). Public Perception on Historical Landscape of Ethnic Immigrant Heritage in Heritage City of Ba ubau. Jurnal Komunitas, 6(2), 312-319. 
Tutiasri, R.P. (2016). Komunikasi dalam Komunikasi Kelompok. Channel: Jurnal Komunikasi, 4(1), 81-90.

Wiwaha, A.A., Mei, E.T.W., dan Rachmawati, R. (2016). Perencanaan Partisipatif Ja lur Evakuasi dan Titik Kumpul Desa Ngargomulyo dalam Upaya Pengurangan Resiko Bencana Gunungapi Merapi. JurnalPerencanaan Wilayah dan Kota, 27(1):34-48. 